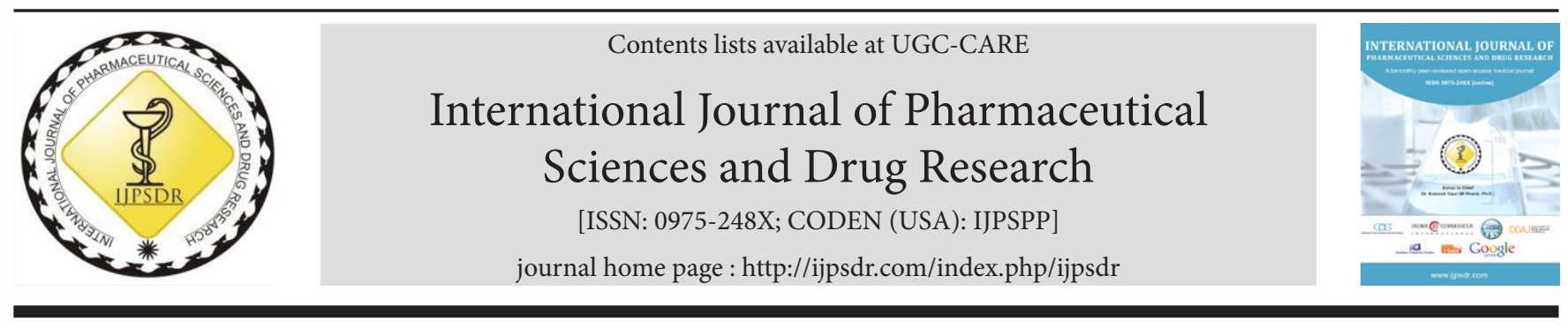

Research Article

\title{
Liposome Encapsulated Astaxanthin altered Biochemical Profile in Diethylnitrosamine induced Hepato Carcinoma on Swiss Albino Mice
}

\author{
Suganya Vasudevan, Anuradha Venkataraman* \\ PG and Research Department of Biochemistry, Mohamed Sathak College of Arts and Science, Sholinganallur-600119, Chennai, Tamil Nadu, India
}

\author{
A R T I C L E I N F O \\ Article history: \\ Received: 08 April, 2020 \\ Revised: 05 June, 2020 \\ Accepted: 19 June, 2020 \\ Published: 30 July, 2020 \\ Keywords: \\ Astaxanthin, \\ Diethylnitrosoamine (DEN), \\ Hepatocellular carcinoma (HCC), \\ Tumor necrosis factor-alpha \\ (TNF- $\alpha$ ). \\ DOI: \\ 10.25004/IJPSDR.2020.120406
}

\begin{abstract}
A B S T R A C T
Cancer is a disease in which a group of abnormal cells grows uncontrollably by disregarding the normal rules of cell division. Across several cancers, hepatocellular carcinoma (HCC) is one of the most aggressive cancers worldwide. It is held responsible for up to 1 million deaths globally per annum. HCC is inflammationrelated cancer, as a chronic inflammatory state is necessary for cancer appearance. In this study, the drug astaxanthin and encapsulated astaxanthin was tested against HCC. Mice were divided into seven groups; group I: control, group II: diethylnitrosamine (DEN) induced, group III: DEN $+50 \mathrm{mg} / \mathrm{kg}$ astaxanthin, group IV: DEN $+100 \mathrm{mg} / \mathrm{kg}$ astaxanthin, group V: DEN $+50 \mathrm{mg} / \mathrm{kg}$ encapsulated astaxanthin, group VI: $\mathrm{DEN}+100 \mathrm{mg} / \mathrm{kg}$ encapsulated astaxanthin, and group VII: DEN $+10 \mathrm{mg} / \mathrm{kg}$ sorafenib. Regular diet was given. Body weight, food intake, and water intake were noted. Other biochemical parameters, such as, alkaline phosphatase (ALP), aspartate aminotransferase (AST), albumin, proteins, and tumor necrosis factor-alpha (TNF- $\alpha$ ), were determined. Finally, the liver was removed from each mice of different groups by sacrificing them, and histopathology was done. In vivo evaluation in mice models showed significant antitumor activities by both encapsulated and non-encapsulated astaxanthin at $100 \mathrm{mg} / \mathrm{kg}$, as compared with the control, DEN induced group, and positive drug sorafenib. This research suggested that encapsulated astaxanthin can also be used as chemotherapeutic agent for the treatment of HCC.
\end{abstract}

\section{INTRODUCTION}

Various studies have been proved thelinks between humans and diet. $^{[1,2]}$ Numerous substances naturally present in foodstuffs, particularly anti-oxidant compounds, have shown a promising effect as potential chemopreventive agents. ${ }^{[3-5]}$ Among these phytonutrients, the yellow, orange, and red carotenoid pigments have recently sparked much interest. Several naturally occurring carotenoids other than $\beta$-carotene have exhibited anticancer activity, ${ }^{[6-9]}$ and are being considered further as potential chemopreventive agents. Among these carotenoids, the red pigment astaxanthin is of particular interest in health management due to its unique structural and chemical properties. ${ }^{[10,11]}$ Among various carotenoids, the red pigment astaxanthin shows particular interest in the health field, is widely distributed in shrimp, salmon, crab, and asteroidean. ${ }^{[6]}$ Astaxanthin was approved by the United States Food and Drug Administration (USFDA) in 1987 as a feed additive for use in the aquaculture production. And in 1999, it was approved for use in nutraceutical industry as a dietary supplement. ${ }^{[8]}$ When compared to other carotenoids, such as, canthaxanthin, lutein, zeaxanthin, and $\beta$-carotene, more powerful antioxidative property was produced by astaxanthin. ${ }^{[9]}$ The two oxygenated groups on each ring structure were responsible for its anti-oxidant features (Fig. 1). ${ }^{[10]}$ It has<smiles>CC1=C(/C=C/C(C)=C/C=C/C(C)=C/C=C/C=C(C)/C=C/C=C(C)/C=C/C2=C(C)C(C)(C)CC(O)C2=O)C(C)(C)CC(O)C1=O</smiles>

Fig. 1: Chemical structure of astaxanthin

\footnotetext{
${ }^{*}$ Corresponding Author: Anuradha Venkataraman

Address: PG and Research Department of Biochemistry, Mohamed Sathak College of Arts and Science, Sholinganallur-600119, Chennai, Tamil Nadu, India Email $\square$ : vanuradha2712@gmail.com

Tel.: +91-9841751450

Relevant conflicts of interest/financial disclosures: The authors declare that the research was conducted in the absence of any commercial or financial relationships that could be construed as a potential conflict of interest.

Copyright (C) 2020 Suganya Vasudevan et al. This is an open access article distributed under the terms of the Creative Commons AttributionNonCommercial-ShareAlike 4.0 International License which allows others to remix, tweak, and build upon the work non-commercially, as long as the author is credited and the new creations are licensed under the identical terms.
} 
been proved that both in vivo and in vitro astaxanthin could protect against neurotoxin or oxidative stress-induced damage ${ }^{[11,12]}$ Many researches have proved astaxanthin as an anti-oxidant therapeutic agent in models of brain injury ${ }^{[13-15]}$ and cardiovascular disease..$^{[16,17]}$ Moreover, at least eight clinical studies have been conducted in cardiovascular disease to evaluate the dosing, bioavailability, and safety of astaxanthin. ${ }^{[18]}$ Notably, no significant side effects of astaxanthin have been reported so far. Among its potent anti-oxidative effects, evidence also suggests that astaxanthin has anti-cancer efficacy in multiple types of cancer, including oral cancer ${ }^{[19]}$ bladder carcinogenesis, ${ }^{[20]}$ colon carcinogenesis, ${ }^{[21,22]}$ leukemia, ${ }^{[23]}$ and HCC. ${ }^{[24,25]}$

Sorafenib (Nexavar) is a small molecule that inhibits tumor-cell proliferation and tumor angiogenesis, and increases the rate of apoptosis in a wide range of tumor models. The main action of sorafenib is by inhibiting the serine-threonine kinases Raf- 1 and B-Raf, and the receptor tyrosine kinase activity of 1,2 , and 3 vascular endothelial growth factor receptors (VEGFRs) and platelet-derived growth factor receptor $\beta$ (PDGFR- $\beta$ ). Cellular signaling that is mediated by the Raf- 1 and vascular endothelial growth factor (VEGF) pathways have been implicated in the molecular pathogenesis of HCC, providing a rationale for investigating sorafenib for this indication. In preclinical experiments, sorafenib had anti-proliferative activity in liver cancer cell lines, and it reduced tumor angiogenesis and tumor-cell signaling, and increased tumor-cell apoptosis in a mouse xenograft model of human HCC. ${ }^{[26]}$

HCC is a malignant tumor of the digestive system and has a high mortality rate worldwide. Jemal and colleagues reported that the incidence of HCC has continuously increased in recent years and is the fifth most common cancer and the third leading cause of cancer death. ${ }^{[27]}$ HCC is a complex disease due to its polygenic, multifactorial, multi-stage evolution, and insidious onset, it is difficult to detect early, metastasizes easily, and is insensitive to chemotherapy. ${ }^{[28,29]}$ The protective effect of astaxanthin in human HCC cells has been rarely reported. Therefore, the application of astaxanthin in animal models requires a better understanding of its potential protective effects in human HCC and the corresponding molecular mechanisms, which may result in the development of astaxanthin for HCC patients.

Previous studies have indicated that inflammation is closely associated with HCC development. Persistent infection with either hepatitis B or hepatitis $C$ virus, one of the major risk factors of HCC, induces chronic inflammation, and subsequent cirrhosis, thus, promoting HCC initiation and progression. ${ }^{[30,31]}$ HCC patients with high levels of inflammation, marked by increased levels of inflammatory cytokines and cells, tend to have a poor prognosis. ${ }^{[32,33]}$ Pro-inflammatory cytokines, including TNF- $\alpha$, interleukin (IL)-1 $\beta$, and IL- 6 , are the principal mediators of tumor- accelerating inflammation. ${ }^{[34-36]}$ Consequently, targeting tumor-accelerating pro-inflammatory cytokines may perhaps effect in HCC tumor regression.

TNF- $\alpha$ was initially identified by its ability to induce lysis in tumor cells. ${ }^{[37]}$ TNF- $\alpha$ exhibit two forms, such as, cell membrane-bound form and a soluble form. Two types of TNF- $\alpha$ receptors, TNF- $\alpha$ receptors 1 and 2, which are either cell membrane-bound or soluble, have been classified so far. ${ }^{[37,38]}$ Although TNF- $\alpha$ was initially identified as a tumor-killing cytokine, further studies have determined that it serves a more complex role in cancer development. ${ }^{[37]}$ Furthermore, TNF- $\alpha$ is a key mediator of the cancer-associated inflammatory networks that have strong tumor-promoting properties. ${ }^{[39,40]}$ Preclinical studies in various types of cancer, including breast, pancreatic, and blood cancer, have suggested that TNF- $\alpha$ stimulates tumor growth in vivo and that anti-TNF- $\alpha$ treatments may suppress tumor progression. ${ }^{[41-43]}$ Previous studies have demonstrated that the level of serum TNF- $\alpha$ and a number of other pro-inflammatory cytokines were significantly higher in patients with HCC compared with healthy individuals, thus, increased TNF- $\alpha$ was associated with the occurrence of HCC. ${ }^{[44,45]}$ High levels of TNF- $\alpha$ were also associated with increased inflammation in patients with chronic viral hepatitis C. ${ }^{[46]}$ These results suggest that TNF- $\alpha$ serves an important role in regulating inflammation in HCC. The present study was designed to compare the effects of encapsulated and non-encapsulated astaxanthin on HCC in mice models.

\section{MATERIALS AND METHODS}

\section{Sample Preparation}

\section{Non-Encapsulated Astaxanthin}

Astaxanthin, the red color powder, was purchased from Rudra Bio Ventures Pvt. Ltd., Bangalore.

\section{Liposome Encapsulated Astaxanthin}

The method for production of liposome-encapsulated astaxanthin was prepared using: L-phosphatidylcholine $[0.04 \mathrm{~g} / \mathrm{mL}$ of dimethyl sulfoxide (DMSO)] and cholesterol $(0.01 \mathrm{~g} / \mathrm{mL}$ of DMSO), which were liquefied in $5 \mathrm{~mL}$ of mixed solvent of chloroform/methanol $(2: 1 \mathrm{v} / \mathrm{v})$. To this mixture, an applicable amount of astaxanthin was added. To sum up, concentration of astaxanthin was made to $1 \mathrm{mM}$. The above mixture was ultra-sonicated and concentrated under decreased pressure to totally drive-off the organic solvents until a membranous product formed on the inner wall of the concentrator. The desiccation process was carried out for another 2 hours in a vacuum drier. The product membrane was dissolved in $15 \%$ of ethanol/double distilled water. The solution was sonicated in probe sonicator for 30 minutes. The dispersal was filtered through a $0.2 \mu \mathrm{m}$ membrane. The filtrate 
was lyophilized to obtain liposome-encapsulated astaxanthin. ${ }^{[47,48]}$

\section{Positive Drug}

Sorafenib dose of $10 \mathrm{mg} / \mathrm{kg} /$ day was used, which leads to disclosures in the range of the respective human dose of $160 \mathrm{mg} /$ day. $^{[49]}$

\section{Preparation of DEN}

A 1\% DEN was prepared by using $99 \mathrm{~mL}$ of normal saline $\mathrm{NaCl}$ ( 0.9 percent) solution, to which was added $1 \mathrm{~mL}$ of concentrated DEN solution $(0.01 \mu \mathrm{g} / \mu \mathrm{L})$.

\section{Experimental Animals}

Swiss albino mice (20-25 grams) bought from Central Animal House Facility of Kings Institute, Chennai, India, were used to test anti-cancer activity of astaxanthin. These animals were kept in polypropylene cages, which were maintained at a temperature of $22 \pm 2^{\circ} \mathrm{C}$, with a relative humidity of $60 \pm 10 \%$. Standard animal diet (Biogen Foods, India) and water ad libitum was given. Before the starting, the experiment animals were acclimatized to laboratory conditions with 12-hour light/dark cycles. Experiments were designed and conducted in accordance with ethical norms approved by the Institutional Animal Ethical Committee.

Mice were divided into seven groups; each group consists of six animals. Mice of group I served as normal control. HCC was induced in groups II, III, IV, V, and VI, which received DEN (3.5 $\mu \mathrm{L} / \mathrm{gm})$ intraperitoneally, once in a week for eight consecutive weeks. After 2 weeks of DEN administration, the carcinogenic effect was promoted through subcutaneous injections of $\mathrm{CCl}_{4}$ ( $3 \mathrm{~mL} / \mathrm{kg} /$ week) for 8 weeks, after administration of DEN, test groups III and IV were administered orally with 50 and $100 \mathrm{mg} / \mathrm{kg}$ liposomal encapsulated astaxanthin (E.Asx), and V, VI receive with 50 and $100 \mathrm{mg} / \mathrm{kg}$ of nonencapsulated astaxanthin (NE.Asx), respectively, in the form of suspension, daily once a day, and group VII receive with $10 \mathrm{mg} / \mathrm{kg}$ of sorafenib. At the end of experiments, the body weight, water, and food intake of each mice were taken before sacrifice. The mice were killed by cervical decapitation, followed by overnight fasting. Blood was collected by heart puncture and allowed to clot before centrifugation at $1,000 \times$ grams for 10 minutes at $4^{\circ} \mathrm{C}$ to separate serum. The liver tissue was washed twice with ice-cold $0.1 \mathrm{M}$ phosphate buffer saline (PBS, 1:9), pH 7.4, blotted, dried, and weighed. The relative liver weight was calculated as the percentage ratio of liver weight to the body weight. A small portion of the tissue was fixed in formalin for histological examination.

\section{Serum Biochemical Analysis}

Mice were anesthetized with diethyl ether, and blood samples were withdrawn from the retro-orbital venous plexus. Collected blood samples were allowed to stand for 10 minutes at room temperature, then centrifuged at $4^{\circ} \mathrm{C}$ using cooling centrifuge (Shizmazdu) at 3,000 rpm for 10 minutes. Sera were separated for assessment of levels of aspartate aminotransferase (AST), and alanine aminotransferase (ALT), ALP, total bilirubin, total protein, albumin, superoxide dismutase (SOD), glutathione peroxidase (GPx), and lipid peroxides (LPO), using commercially available colorimetric assay kits as previously described. ${ }^{[50]}$ Moreover, inflammatory markers TNF- $\alpha$ were assessed using ELISA kit (Thermo Fisher).

\section{Statistical Analysis}

The results obtained in this research were displayed as mean \pm SEM. Data analysis was done using one-way ANOVA followed by Dunnett's multiple comparison test (FigurePad Prism 5 Software Inc., La Jolla, CA, USA). Values were considered significant at $\mathrm{p}<0.05$.

\section{RESULTS}

Animals were induced by DEN-CCl ${ }_{4}$ to each group except the normal control, and their activities were determined using physical observations. Primary activities, like body weight, convulsion, lacrimation, salivation, defecation, locomotion, rearing, etc., were interpreted and noted in Table 1.

Body weight tends to decreases in both DEN induced group and astaxanthin treated group. Body tone was reduced in the entire mice group except normal. Urination, muscle gripness, and lacrimation were founded to be normal in all the groups. Rearing was normal in control; mild in DEN induced and slows in drug-treated groups. Locomotion was founded to be normal in control, whereas it was very slow in DEN treated and slow in drug-treated groups. Sorafenib induced group shows normal physical activities, but moderate locomotion and rearing were seen. The overall physical examination was normal in control, very poor in DEN treated, and mild in DEN induced drug-treated groups.

As shown in Fig. 2, body weight of each mice of different groups has been noted. The results analyzed by the control group were significantly similar to DEN $+\mathrm{CCl}_{4}$ induced group. The initial weight of control and DEN induced group shows 29.13 and 28.41 grams, which tend to decreases up to 25.34 and 24.42 grams, respectively. Whereas, the

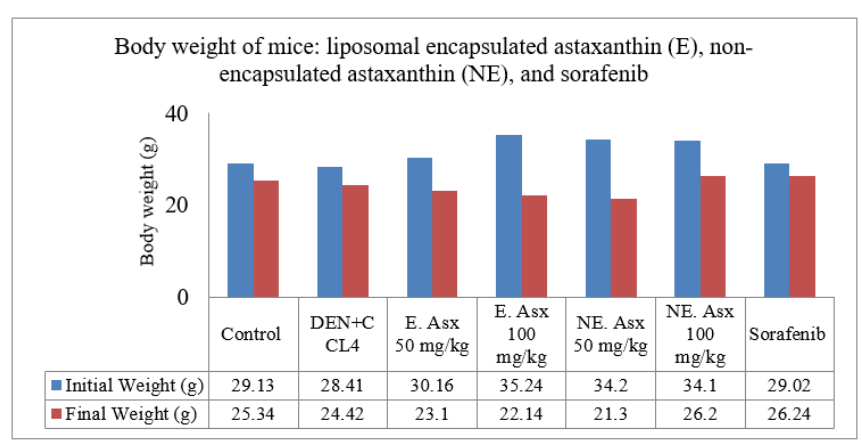

Fig. 2: Body weight evaluation of mice in different groups 
Suganya Vasudevan et al.

Table 1: Physical examination of normal and tested mice

\begin{tabular}{|c|c|c|c|c|c|c|c|}
\hline Group & Control & DEN induced & $\begin{array}{l}\text { E. Asx } \\
50 \mathrm{mg} / \mathrm{kg}\end{array}$ & $\begin{array}{l}\text { E. Asx } \\
100 \mathrm{mg} / \mathrm{kg}\end{array}$ & $\begin{array}{l}\text { NE. AsX } \\
50 \mathrm{mg} / \mathrm{kg}\end{array}$ & $\begin{array}{l}\text { NE. AsX } \\
100 \mathrm{mg} / \mathrm{kg}\end{array}$ & $\begin{array}{l}\text { Sorafenib } \\
10 \mathrm{mg} / \mathrm{kg}\end{array}$ \\
\hline Body weight & Normal & Reduced & Reduced & Reduced & Reduced & Reduced & Normal \\
\hline $\begin{array}{l}\text { Assessments of } \\
\text { posture }\end{array}$ & Normal & Normal & Normal & Normal & Normal & Normal & Normal \\
\hline $\begin{array}{l}\text { Signs of convulsion } \\
\text { Limb paralysis }\end{array}$ & Normal & $\begin{array}{l}\text { Absence of } \\
\text { sign }(-)\end{array}$ & $\begin{array}{l}\text { Absence of sign } \\
(-)\end{array}$ & $\begin{array}{l}\text { Absence of } \\
\text { sign }(-)\end{array}$ & $\begin{array}{l}\text { Absence of sign } \\
(-)\end{array}$ & $\begin{array}{l}\text { Absence of } \\
\text { sign }(-)\end{array}$ & Normal \\
\hline Body tone & Normal & Reduced & Reduced & Reduced & Reduced & Reduced & Normal \\
\hline Lacrimation & Normal & Normal & Normal & Normal & Normal & Normal & Normal \\
\hline Salivation & Normal & Absence & Absence & Normal & Absence & Normal & Normal \\
\hline Change in skin color & $\begin{array}{l}\text { NS color } \\
\text { change }\end{array}$ & $\begin{array}{l}\text { Change in skin } \\
\text { color }\end{array}$ & $\begin{array}{l}\text { Change in skin } \\
\text { color }\end{array}$ & $\begin{array}{l}\text { Change in skin } \\
\text { color }\end{array}$ & $\begin{array}{l}\text { Change in skin } \\
\text { color }\end{array}$ & $\begin{array}{l}\text { Change in skin } \\
\text { color }\end{array}$ & $\begin{array}{l}\text { NS color } \\
\text { change }\end{array}$ \\
\hline Piloerection & Normal & Severe erect & Moderate erect & Mild erect & Mild erect & Mild erect & Normal \\
\hline Sensitivity response & Normal & Abnormal & Normal & Normal & Normal & Normal & Normal \\
\hline Locomotion & Normal & Very slow & Slow & Slow & Slow & Slow & Moderate \\
\hline Rearing & Normal & Mild & Slow & Slow & Slow & Slow & Moderate \\
\hline Urination & Normal & Normal & Normal & Normal & Normal & Normal & Normal \\
\hline
\end{tabular}

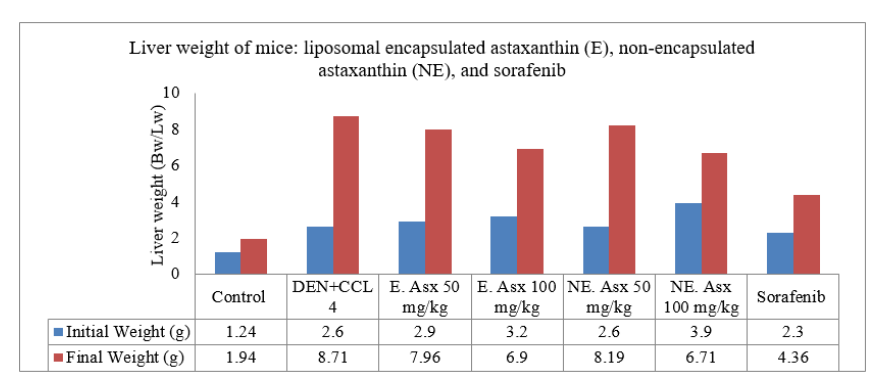

Fig. 3: Liver weight evaluation of mice in different groups

drug-treated groups (liposomal encapsulated astaxanthin 50 and $100 \mathrm{mg} / \mathrm{kg}$; non-encapsulated astaxanthin 50 and $100 \mathrm{mg} / \mathrm{kg}$ ) show lower growth in body weight. The mice which received the drug liposomal encapsulated astaxanthin of 50 and $100 \mathrm{mg} / \mathrm{kg}$ shows initial weight of 30.16 and 35.24 grams, which declines to final weight of 23.1 and 22.14 grams, respectively. Similarly, the mice induced by the drug non-encapsulated astaxanthin 50 and $100 \mathrm{mg} / \mathrm{kg}$ showed 21.3 and 26.2 grams final weight, respectively, from 34.2 and 34.1 grams, as initial weight. The positive drug-induced mice show 29.02 as initial weight and 26.24 grams as final weight, which indicates that the mice affected with HCC shows gradual decrease in the body weight.

The liver weight was evaluated for the mice of different group, since DEN was induced to cause HCC, which is represented in Fig. 3. The initial and final liver weight of control group was founded to be normal, which shows 1.24 to $1.94 \mathrm{Bw} / \mathrm{Lw}$, but the DEN induced group shows severe weight gain in liver from 2.6 to 8.71 grams. The other test groups, such as, liposomal encapsulated astaxanthin and non-encapsulated astaxnthin of 50 and $100 \mathrm{mg} / \mathrm{kg}$ shows depleted increase in liver weight, which differs between initial and final weight of liver, but compare to DEN induced

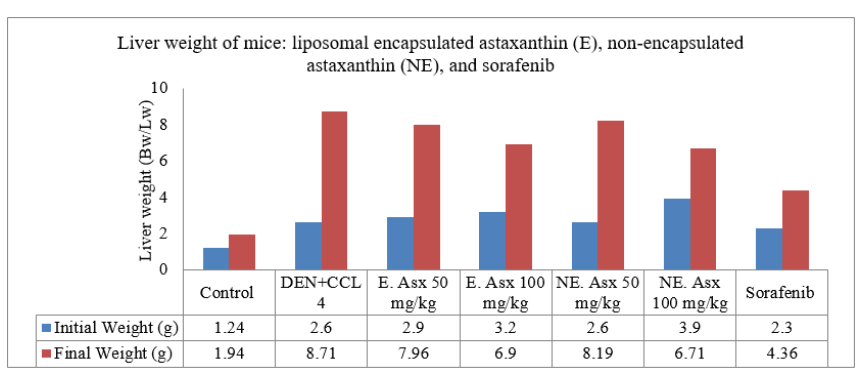

Fig. 4: Water intake by mice in different groups

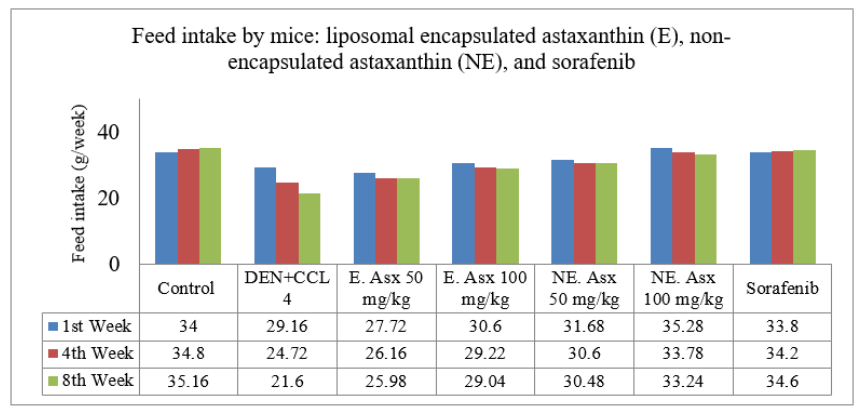

Fig. 5: Feed intake by mice in different groups

the mice of drug-induced groups shows moderate liver weight gain. The liver weight of mice in sorafenib induced group also shows slight variation from 2.3 to $4.36 \mathrm{Bw} / \mathrm{Lw}$, respectively.

Water intake by the mice of different groups has been calculated at 1 st, 4 th, and 8 th week after inducing the drug and denoted in Fig. 4. Water intake by DEN (only) and liposomal encapsulated astaxanthin of $50 \mathrm{mg} / \mathrm{kg}$ induced mice was very poor, when compared with control, other test drug, and positive drug mice group.

Fig. 5 indicated the net amount of feed intake by mice for 1st, 4th, and 8th week after administration of DEN, 
astaxanthin, encapsulated astaxanthin, and sorafenib. When compared with control, liposomal encapsulated astaxanthin of $100 \mathrm{mg} / \mathrm{kg}$, non-encapsulated astaxanthin of 50 and $100 \mathrm{mg} / \mathrm{kg}$, and sorafenib induced groups show similar feed intake, while other two group such as, DEN (only) and liposomal encapsulated astaxanthin $50 \mathrm{mg} / \mathrm{kg}$ shows lower feed intake, which may be due to some difficulties during HCC.

The level of ALT, AST, and ALP in control was found to be in normal range, i.e., 71.04, 124.02, and 267.28 (U/L), which tends to increase in DEN induced group [ALT: 128.21 (U/L); AST: 428.02 (U/L); ALP: 560.68 (U/L)]. But after the administration of test drug, the elevated level of ALT, AST, and ALP was suppressed in liposomal encapsulated astaxanthin $50 \mathrm{mg} / \mathrm{kg}$ [ALT: 116.41 (U/L); AST: 368.44 (U/L); ALP: 490.82 (U/L)], liposomal encapsulated astaxanthin $100 \mathrm{mg} / \mathrm{kg}$ [ALT: 97.36 (U/L); AST: 242.33 (U/L); ALP: 372.40 (U/L)], non-encapsulated astaxanthin $50 \mathrm{mg} / \mathrm{kg}$ [ALT: 106.20 (U/L); AST: 298.20 (U/L); ALP: 422.33 (U/L)], non-encapsulated astaxanthin $100 \mathrm{mg} / \mathrm{kg}$ [ALT: 90.46 (U/L); AST: 188.63 (U/L); ALP: $287.72(\mathrm{U} / \mathrm{L})]$, and sorafenib $10 \mathrm{mg} /$ kg [ALT: 92.20 (U/L); AST: 178.36 (U/L); ALP: 279.32 (U/L)] (Fig. 6 and Table 2).

The mean values of blood factors, such as, total protein $(\mathrm{g} / \mathrm{dL})$, total bilirubin $(\mathrm{mg} / \mathrm{dL})$, albumin $(\mathrm{U} / \mathrm{L})$, SOD (U/mg protein), GPx (U/mg protein), and LPO (mmol/ mg protein) were determined, and values were given in Fig. 7 and Table 3. The liposomal encapsulated astaxanthin and non-encapsulated astaxanthin suppress the elevated level of total protein, total bilirubin, and albumin, when compared to DEN (only) induced group. Significant higher level of total protein was observed for DEN induced group than other groups. SOD and GPx activities were high in the DEN treated mice, when compared to control group,

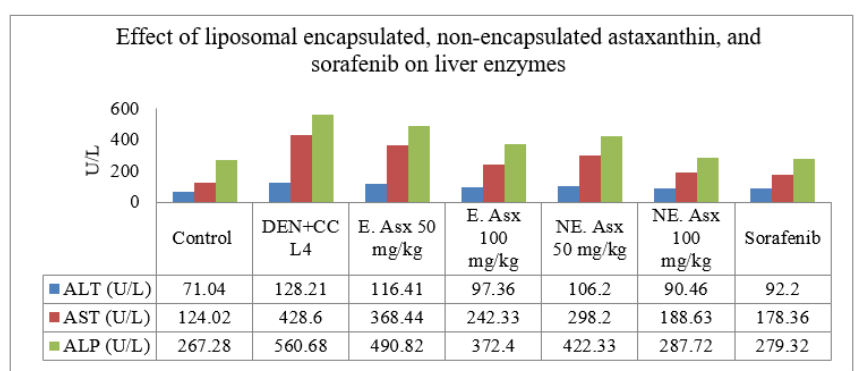

Fig. 6: Effect of treatment with liposomal encapsulated, non-encapsulated astaxanthin, and sorafenib on liver marker enzymes in hepatocellular carcinoma mice of different groups

Effect of liposomal encapsulated, non-encapsulated astaxanthin, and sorafenib on blood factors

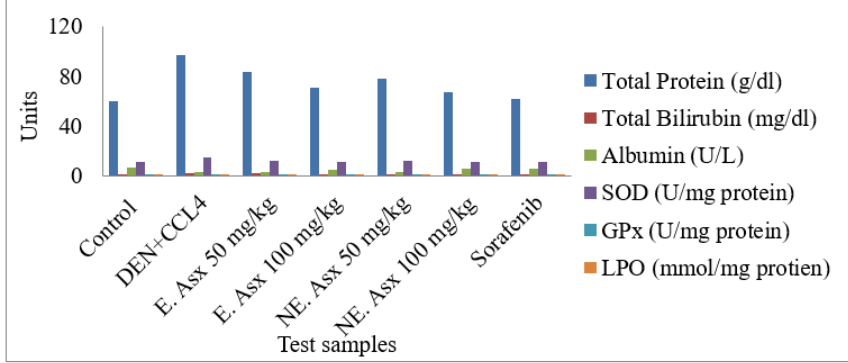

Fig. 7: Effect of treatment with liposomal encapsulated, non-encapsulated astaxanthin, and sorafenib on blood factors in hepatocellular carcinoma mice of different groups

Table 2: Activity of test drug on liver marker enzymes

\begin{tabular}{llll}
\hline Sample/ Test name & ALT $(U / L)$ & $A S T(U / L)$ & $A L P(U / L)$ \\
\hline Control & $71.04 \pm 0.213$ & $124.02 \pm 0.036$ & $267.28 \pm 0.032$ \\
DEN + CCL4 & $128.21 \pm 0.223$ & $428.6 \pm 0.089$ & $560.68 \pm 0.063$ \\
E. Asx $50 \mathrm{mg} / \mathrm{kg}$ & $116.41 \pm 0.132$ & $368.44 \pm 0.023$ & $490.82 \pm 0.162$ \\
E. Asx $100 \mathrm{mg} / \mathrm{kg}$ & $97.36 \pm 0.162$ & $242.33 \pm 0.017$ & $372.4 \pm 0.102$ \\
NE. Asx $50 \mathrm{mg} / \mathrm{kg}$ & $106.2 \pm 0.006$ & $298.2 \pm 0.045$ & $422.33 \pm 0.213$ \\
NE. Asx $100 \mathrm{mg} / \mathrm{kg}$ & $90.46 \pm 0.035$ & $188.63 \pm 0.061$ & $287.72 \pm 0.310$ \\
Sorafenib & $92.2 \pm 0.106$ & $178.36 \pm 0.092$ & $279.32 \pm 0.156$ \\
\hline
\end{tabular}

NS-Not significant; ${ }^{* *}(\mathrm{p}>0.01) ;{ }^{*}(\mathrm{p}>0.05) ; \mathrm{n}=10$; values are mean \pm SD (one-way ANOVA followed by Dunnett's test)

Table 3: Activity of test drug on blood factors

\begin{tabular}{lllllll}
\hline Sample/Test name & $\begin{array}{l}\text { Total protein } \\
(\mathrm{g} / \mathrm{dL})\end{array}$ & $\begin{array}{l}\text { Total bilirubin } \\
(\mathrm{mg} / \mathrm{dL})\end{array}$ & $\begin{array}{l}\text { Albumin }(\mathrm{U} / \mathrm{L}) \\
\text { Control }\end{array}$ & $\begin{array}{l}\text { SOD }(\mathrm{U} / \mathrm{mg} \\
\text { protein })\end{array}$ & $\begin{array}{l}\text { GPx }(\mathrm{U} / \mathrm{mg} \\
\text { protein })\end{array}$ & $\begin{array}{l}\mathrm{LPO}(\mathrm{mmol} / \mathrm{mg} \\
\text { protien })\end{array}$ \\
DEN + CCL4 & $96.98 \pm 0.03$ & $0.72 \pm 0.008$ & $6.8 \pm 0.067$ & $11.02 \pm 0.122$ & $0.0125 \pm 0.230$ & $0.0035 \pm 0.235$ \\
E. Asx $50 \mathrm{mg} / \mathrm{kg}$ & $83.36 \pm 0.120$ & $1.46 \pm 0.13$ & $3.1 \pm 0.128$ & $11.55 \pm 0.032$ & $0.0312 \pm 0.138$ & $0.0426 \pm 0.038$ \\
E. Asx $100 \mathrm{mg} / \mathrm{kg}$ & $71.09 \pm 0.003$ & $1.06 \pm 0.361$ & $4.8 \pm 0.004$ & $10.59 \pm 0.561$ & $0.0281 \pm 0.209$ & $0.0389 \pm 0.162$ \\
NE. Asx $50 \mathrm{mg} / \mathrm{kg}$ & $78.22 \pm 0.23$ & $1.24 \pm 0.031$ & $2.9 \pm 0.01$ & $12.06 \pm 0.106$ & $0.0356 \pm 0.213$ & $0.0416 \pm 0.189$ \\
NE. Asx $100 \mathrm{mg} / \mathrm{kg}$ & $66.78 \pm 0.162$ & $0.96 \pm 0.009$ & $5.4 \pm 0.318$ & $11.33 \pm 0.267$ & $0.0302 \pm 0.003$ & $0.0341 \pm 0.056$ \\
Sorafenib & $62.03 \pm 0.145$ & $0.89 \pm 0.021$ & $5.7 \pm 0.019$ & $10.65 \pm 0.268$ & $0.0198 \pm 0.009$ & $0.0127 \pm 0.046$ \\
\hline
\end{tabular}

NS-Not significant; ${ }^{* *}(\mathrm{p}>0.01) ;{ }^{*}(\mathrm{p}>0.05) ; \mathrm{n}=10$; values are mean \pm SD (one-way ANOVA followed by Dunnett's test) 
drug-treated group, and positive drug sorafenib. Due to chronic cell changes, anti-oxidant response had been activated. Such alterations could be due to DEN induced inflammation or increased apoptosis. The findings indicate that encapsulated and non-encapsulated astaxanthin exerted an anti-inflammatory action againstDEN-induced.

Treatment withliposomal encapsulated,non-encapsulated astaxanthin and sorafenib showed a significant decrease in the inflammatory marker (TNF- $\alpha$ ), thereby indicating

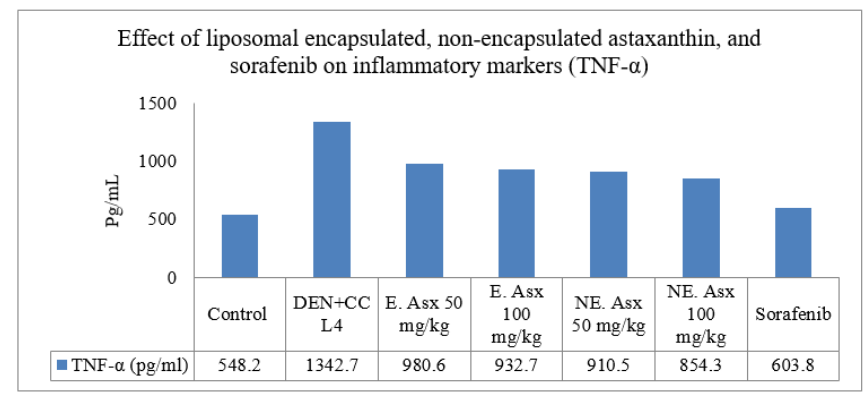

Fig. 8: Effect of treatment with liposomal encapsulated, non-encapsulated astaxanthin, and sorafenib on inflammatory markers

(TNF- $\alpha$ ) in hepatocellular carcinoma mice of different groups

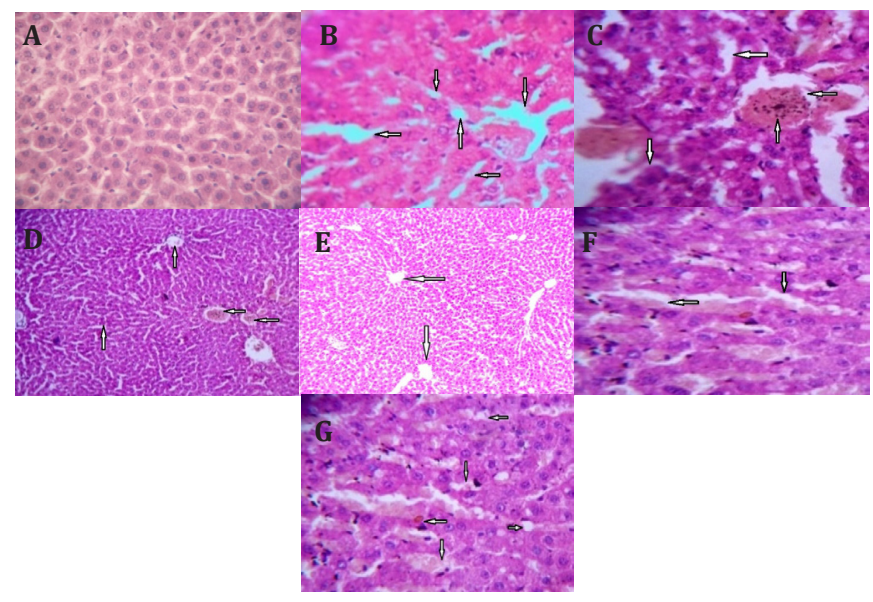

Fig. 9: Histopathology image of liver: control group and DEN treated group

Note: A-Control; B-DEN induced; C-Non-encapsulated astaxanthin $(50 \mathrm{mg} / \mathrm{kg}) ;$ D-Non-encapsulated astaxanthin $(100 \mathrm{mg} / \mathrm{kg})$; E-Encapsulated astaxanthin (50 mg/kg); F-Encapsulated astaxanthin (100 mg/kg); G-Sorafenib (10 mg/kg)

Table 4: Activity of test samples on inflammatory marker

\begin{tabular}{ll}
\hline Sample/Test name & TNF- $\alpha(\mathrm{pg} / \mathrm{mL})$ \\
\hline Control & $548.2 \pm 0.137$ \\
DEN + CCL4 & $1,342.7 \pm 0.203$ \\
E. Asx $50 \mathrm{mg} / \mathrm{kg}$ & $980.6 \pm 0.032$ \\
E. Asx $100 \mathrm{mg} / \mathrm{kg}$ & $932.7 \pm 0.103$ \\
NE. Asx $50 \mathrm{mg} / \mathrm{kg}$ & $910.5 \pm 0.006$ \\
NE. Asx $100 \mathrm{mg} / \mathrm{kg}$ & $854.3 \pm 0.034$ \\
Sorafenib $10 \mathrm{mg} / \mathrm{kg}$ & $603.8 \pm 0.612$ \\
\hline
\end{tabular}

NS-Not significant; ${ }^{* *}(\mathrm{p}>0.01) ;{ }^{*}(\mathrm{p}>0.05) ; \mathrm{n}=10$; values are mean \pm SD (one-way ANOVA followed by Dunnett's test) the anti-inflammatory activity of astaxanthin, both in encapsulated and non-encapsulated form. These results indicate similar effect on the HCC by astaxanthin, when compared with control and positive drug sorafenib. Control group shows $548.2 \mathrm{pg} / \mathrm{mL}$ of TNF- $\alpha$ in mice blood sample. Elevated level of $1,342.7 \mathrm{pg} / \mathrm{mL}$ was found in DEN induced group, this tend to decrease to the level of 980.6, 932.7, $910.5,854.3$, and $603.8 \mathrm{pg} / \mathrm{mL}$ in E.Asx $50 \mathrm{mg} / \mathrm{kg}$, E.Asx $100 \mathrm{mg} / \mathrm{kg}$, NE.Asx $50 \mathrm{mg} / \mathrm{kg}$, NE.Asx $100 \mathrm{mg} / \mathrm{kg}$, and sorafenib $10 \mathrm{mg} / \mathrm{kg}$, respectively (Fig. 8 and Table 4).

Liver section of each group mice was tested for histopathological analysis. From the result, the control group mice showed normal liver structural design and normal appearance of the hepatocytes. The liver sinusoids were seen in between the adjacent plates. Kupffer cells were also seen associated with the sinusoidal lining cells (Fig. 9A). However, DEN $+\mathrm{CCl}_{4}$ is highly mutagenic in mice showed loss of lobular architecture, hence, showed stronger fibrosis and tumor necrosis of hepatic tissues, which was represented in Fig. 9B.

The histopathological changes in the livers of the liposomal encapsulated astaxanthin of $50 \mathrm{mg} / \mathrm{kg}$ bw treated mice give the impression of neoplastic changes in liver section and reduced the severity of lesions in liver, when compared with untreated control and DEN treated group (Fig. 9C). Group treated with higher dose of liposomal encapsulated astaxanthin of $100 \mathrm{mg} / \mathrm{kg}$ bw after the induction of HCC showed reduced degeneration and distortion of hepatocytes and marked transformation of hepatic manner with restoration of bile duct structure. Similarly, less fatty changes and minimal pleomorphic was also noted compared to normal control and HCC control (Fig. 9D).

In parallel, the histopathological image of liver treated with non-encapsulated astaxanthin of $100 \mathrm{mg} / \mathrm{kg}$ bw after the formation of liver tumor showed nucleated cells with slight improvement in liver cells than $50 \mathrm{mg} / \mathrm{kg}$ bw of non-encapsulated astaxanthin which showed steatosis, micro and macro vesicles, cytoplasmic degeneration, Kupffer cells activation, hemorrhage, and infiltration of inflammatory cells (Figs 9E and F).

The group treated with positive drug sorafenib after the administration of DEN $+\mathrm{CCl}_{4}$ were also examined. It discovered the fewer pathological changes compared to HCC control group, i.e., DEN $+\mathrm{CCl}_{4}$ treated group. The liver sections of sorafenib treated group revealed less fatty changes, less disarrangement, minimal pleomorphic, vacuolation, and degeneration of hepatocytes, and the result of this research reveals that there is no much difference between the test drug and sorafenibadministered group (Fig. 9G).

\section{DISCUSSION}

Natural products have been considered as important sources that could create prospective chemotherapeutic 
agents. Apparently, natural products are an extremely important source of medicinal agents. While, there are some new approaches to drug discovery, such as, combinatorial chemistry and computer-based molecular modeling design, none of them can replace the reputation of natural products in drug discovery and development.

In this study, we demonstrated the antitumor effects of astaxanthin and encapsulated astaxanthin against HCC. According to our interpretation, both encapsulated and non-encapsulated astaxanthin at higher dose of $100 \mathrm{mg} / \mathrm{kg}$ shows moderate anti-cancer activity in mice while a lower dose of $50 \mathrm{mg} / \mathrm{kg}$ of encapsulated and non-encapsulated astaxanthin showed mild activity. This was compared with the control, DEN induced, and positive drug sorafenib. The positive drug sorafenib shows good anti-cancer activity when compared with other groups.

Signaling pathways that are connected with HCC carcinogenesis promote angiogenesis, enhance growth, and inhibit apoptosis, which can result in uncontrolled tumor cell growth. ${ }^{[51]}$ HCC signal transduction may occur through different pathways. (1) angiogenesis-related pathways (e.g., vascular endothelial growth factor, VEGF; platelet-derived growth factor, PDGF; and fibroblast growth factor, FGF), ${ }^{[52]}$ (2) growth-related pathways (e.g., hepatocyte growth factor receptor, HGFR; epidermal growth factor receptor, EGFR; insulin-like growth factor 1 receptor, IGF-1R; PI3K/AKT/mTOR, and Wnt- $\beta$ catenin), ${ }^{[53,54]}$ and (3) HGF/ c-Met pathway. ${ }^{[55]}$

Previous studies have reported that sorafenib is a multi-kinase and tyrosine kinase inhibitor for the treatment of advanced HCC. ${ }^{[2]}$ A 2008 phase III trial has shown that sorafenib significantly extends the survival of patients with advanced HCC. ${ }^{[56]}$ Sorafenib is a multitargeted small molecule that inhibits the activity of VEGF, PDGF, and EGF, as well as, Raf to block tumor proliferation and angiogenesis. ${ }^{[57]}$ The median overall survival in the sorafenib-treated group was 10.7 months, compared with 7.9 months in the placebo group. ${ }^{[2,56]}$ However, the survival benefit was only a few months. In addition, numerous patients required a dose reduction or cessation of treatment because of the adverse effects of the drug, and some patients with renal cancer experienced tumor rebound after discontinuing the drug. ${ }^{[57,58]}$

HCC is complex pathogenesis involving aberrant signaling in several molecular pathways. Sorafenib is a targeted therapy, currently used as a standard treatment for patients with advanced HCC. Sorafenib is a multi-kinase inhibitor that demonstrates activity against several tyrosine (VEGFR and PDGFR) kinases and serine/ threonine (Raf) kinases. ${ }^{[52]}$ The administration of sorafenib has generated promising results for the treatment of HCC patients, and the mechanisms behind the antitumor activities of sorafenib have been wellexplored. ${ }^{[59]}$ In a previous study, the administration of more than $400 \mathrm{mg} /$ day of sorafenib for one-month prolonged progression-free survival in Japanese patients with advanced RCC. ${ }^{[60]}$ Therefore, the management of sorafenib dose to prevent the occurrence of side-effects is a very important topic.

The anti-cancer properties as anti-oxidants have been inviting attention, with research concentrated on energy metabolism and oxidative stress in cancer research. Research by previous studies has proven that ASX at higher doses is non-toxic to mice and human endothelial cells. ${ }^{[61-64]}$ Related clinical studies have also been conducted into cardiovascular disease to assess the dosing, bioavailability, and safety of ASX. ${ }^{[19]}$ To date, no significant side effects related to ASX have been reported. ${ }^{[65]}$ Therefore, this powerful anti-oxidant may be a novel and potential drug for inhibiting the proliferation of carcinoma cells. ${ }^{[66,67]}$ ASX may play an efficient role against cancer by enhancing the immune response in mice, as described by Jyonouchi and colleagues in 2000. ${ }^{[68]}$ Kowshik and other researchers found that ASX induced intrinsic apoptosis not only in oral cancer cells, but also in skin cancer, breast cancer, and neuroblastoma SH-SY5Y cells. ${ }^{[11,68-71]}$ In 2010, Tripathi DN explored the effects of ASX on early hepatocarcinogenesis in rats. ${ }^{[72]}$ In addition, Song and colleagues established that astaxanthin induced mitochondria-mediated apoptosis in rat HCC CBRH-7919 cells by an $\mathrm{IC}_{50}$ of $39 \mu \mathrm{M}$ through inhibition of the JAK/STAT3 signaling pathway. ${ }^{[24,25]}$ Also, another study showed that oral astaxanthin intake during the early developmental stage suppressed MNU-induced rat mammary carcinogenesis. ${ }^{[73]}$

\section{CONCLUSION}

Our studies were correlated with the previous reports, which include the role of encapsulated astaxanthin along with non-encapsulated astaxanthin. So far, pure form of astaxanthin was alone confirmed against HCC; the encapsulated astaxanthin was not performed. Hence, our findings demonstrate that both non-encapsulated and encapsulated astaxanthin has a promising potential therapeutic agent for human HCC, and has anti-oxidant and anti-inflammatory activity.

\section{REFERENCES}

1. Papas AM. Diet and anti-oxidant status, in Anti-oxidant Status. Diet, Nutrition and Health, Papas, A.M., Ed., CRC Press, Boca Raton, Florida, 1998, chap. 5.

2. Chesson A, Collins A. Assessment of the role of diet in cancer prevention. Cancer Lett. 1997;114:281-237.

3. Lee BM, Park KK. Beneficial and adverse effects of chemopreventive agents. Mutat Res. 2003;265:523-524.

4. Sporn MB, Suh N. Chemoprevention: an essential approach to controlling cancer. Nature Rev Cancer. 2002;2:529-537.

5. Wargovich MJ. Experimental evidence for cancer preventive elements in food. Cancer Lett. 1997;114:1-11.

6. Pashkow FJ, Watumull DG, Campbell CL. Astaxanthin: A novel potential treatment for oxidative stress and inflammation in cardiovascular disease. Am J Cardiol. 2008;101:58D-68D.

7. Miki W, Yamaguchi K, Konosu S. Comparison of carotenoids in the ovaries of marine fish and shellfish. Comp Biochem Physiol B. 1982;71(1):7-11. 
8. Guerin M, Huntley ME, Olaizola M. Haematococcus astaxanthin: Applications for human health and nutrition. Trends Biotechnol. 2003;21:210-216.

9. Zhang XS, Zhang X, Zhou ML, Zhou XM, Li N, Li W, et al. Amelioration of oxidative stress and protection against early brain injury by astaxanthin after experimental subarachnoid hemorrhage. J Neurosurg. 2014a;121:42-54.

10. Ikeda Y, Tsuji S, Satoh A, Ishikura M, Shirasawa T, Shimizu T. Protective effects of astaxanthin on 6-hydroxydopamine-induced apoptosis in human neuroblastoma SH-SY5Y cells. J Neurochem. 2008;107:1730-1740.

11. Liu X, Shibata T, Hisaka S, Osawa T. Astaxanthin inhibits reactive oxygen species-mediated cellular toxicity in dopaminergic SH-SY5Y cells via mitochondria-targeted protective mechanism. Brain Res. 2009;1254:18-27.

12. Shen H, Kuo CC, Chou J, Delvolve A, Jackson SN, Post J, et al. Astaxanthin reduces ischemic brain injury in adult rats. FASEB J. 2009;23:1958-1968.

13. Wu Q, Zhang XS, Wang HD, Zhang X, Yu Q, Li W, et al. Astaxanthin activates nuclear factor erythroid-related factor 2 and the antioxidant responsive element (Nrf2-ARE) pathway in the brain after subarachnoid hemorrhage in rats and attenuates early brain injury. Mar Drugs. 2014;12:6125-6141.

14. Zhang XS, Zhang X, Wu Q, Li W, Zhang QR, Wang CX, et al. Astaxanthin alleviates early brain injury following subarachnoid hemorrhage in rats: Possible involvement of Akt/bad signaling. Mar Drugs. 2014b;12:4291-4310.

15. Lu YP, Liu SY, Sun H, Wu XM, Li JJ, Zhu L. Neuroprotective effect of astaxanthin on $\mathrm{H}(2) \mathrm{O}(2)$-induced neurotoxicity in vitro and on focal cerebral ischemia in vivo. Brain Res. 2010;1360:40-48.

16. Gross GJ, Lockwood SF. Cardioprotection and myocardial salvage by a disodium disuccinate astaxanthin derivative (Cardax). Life Sci. 2004;75:215-224.

17. Lauver DA, Lockwood SF, Lucchesi BR. Disodium Disuccinate Astaxanthin (Cardax) attenuates complement activation and reduces myocardial injury following ischemia/reperfusion. J Pharmacol Exp Ther. 2005;314:686-692.

18. Fassett RG, Coombes JS. Astaxanthin, oxidative stress, inflammation and cardiovascular disease. Future Cardiol. 2009;5:333-342.

19. Kavitha K, Kowshik J, Kishore TK, Baba AB, Nagini S. Astaxanthin inhibits NF-kappaB and Wnt/beta-catenin signaling pathways via inactivation of Erk/MAPK and PI3K/Akt to induce intrinsic apoptosis in a hamster model of oral cancer. Biochim Biophys Acta. 2013;1830:4433-4444.

20. Tanaka T, Morishita Y, Suzui M, Kojima T, Okumura A, Mori H. Chemoprevention of mouse urinary bladder carcinogenesis by the naturally occurring carotenoid astaxanthin. Carcinogenesis. 1994;15:15-19.

21. Nagendraprabhu P, Sudhandiran G. Astaxanthin inhibits tumor invasion by decreasing extracellular matrix production and induces apoptosis in experimental rat colon carcinogenesis by modulating the expressions of ERK-2, NFkB and COX-2. Investig. New Drugs. 2011;29:207-224.

22. Yasui Y, Hosokawa M, Mikami N, Miyashita K, Tanaka T. Dietary astaxanthin inhibits colitis and colitis-associated colon carcinogenesis in mice via modulation of the inflammatory cytokines. Chem Biol Interact. 2011;193:79-87.

23. Zhang X, Zhao WE, Hu L, Zhao L, Huang J. Carotenoids inhibit proliferation and regulate expression of peroxisome proliferatorsactivated receptor gamma (PPARgamma) in K562 cancer cells. Arch Biochem Biophys. 2011;512:96-106.

24. Song XD, Zhang JJ, Wang MR, Liu WB, Gu XB, Lv CJ. Astaxanthin induces mitochondria-mediated apoptosis in rat hepatocellular carcinoma CBRH-7919 cells. Biol Pharm Bull. 2011;34:839-844.

25. Song X, Wang M, Zhang L, Zhang J, Wang X, Liu W, et al. Changes in cell ultrastructure and inhibition of JAK1/STAT3 signaling pathway in CBRH-7919 cells with astaxanthin. Toxicol Mech Methods. 2012;22:679-686.

26. Keating GM. Sorafenib: A Review in Hepatocellular Carcinoma. Target Oncol. 2017;12(2):243-253.
27. Jemal A, Bray F, Center MM, Ferlay J, Ward E, Forman D. Global cancer statistics. CA Cancer J Clin. 2011;61:69-90.

28. Merle P, Mornex F. Medical therapies for hepatocellular carcinoma. Cancer Radiother. 2011;15:28-31.

29. Villanueva A, Hernandez-Gea V, Llovet JM. Medical therapies for hepatocellular carcinoma: A critical view of the evidence. Nat Rev Gastroenterol Hepatol. 2013;10:34-42.

30. Lin MV, King LY, Chung RT. Hepatitis C virus-associated cancer. Annu Rev Pathol. 2015;10:345-370.

31. Markowitz GJ, Michelotti GA, Diehl AM, Wang XF. Inflammatory models drastically alter tumor growth and the immune microenvironment in hepatocellular carcinoma. Sci Bull (Beijing). 2015;60:762-772.

32. Kinoshita A, Onoda H, Imai N, Iwaku A, Oishi M, Fushiya N, et al. Comparison of the prognostic value of inflammation-based prognostic scores in patients with hepatocellular carcinoma. Br J Cancer. 2012;107:988-993.

33. Proctor MJ, Morrison DS, Talwar D, Balmer SM, O'Reilly DS, Foulis AK, et al. An inflammation-based prognostic score (mGPS) predicts cancer survival independent of tumour site: A glasgow inflammation outcome study. Br J Cancer. 2011;104:726-734.

34. Lasry A, Ben-Neriah Y. Senescence-associated inflammatory responses: Aging and cancer perspectives. Trends Immunol. 2015;36:217-228.

35. Xu J, Yin Z, Cao S, Gao W, Liu L, Yin Y, et al. Systematic review and meta-analysis on the association between IL-1B polymorphisms and cancer risk. PLoS One. 2013;8:e63654.

36. Mantovani A, Allavena P, Sica A, Balkwill F. Cancer-related inflammation. Nature. 2008;454:436-444.

37. Chu WM. Tumor necrosis factor. Cancer Lett. 2013;328:222-225.

38. Engelmann H, Holtmann H, Brakebusch C, Avni YS, Sarov I, Nophar $\mathrm{Y}$, et al. Antibodies to a soluble form of a tumor necrosis factor (TNF) receptor have TNF-like activity.J Biol Chem. 1990;265:14497-14504.

39. Mocellin S, Rossi CR, Pilati P, Nitti D. Tumor necrosis factor, cancer and anti-cancer therapy. Cytokine Growth Factor Rev. 2005;16:35-53.

40. Zins K, Abraham D, Sioud M, Aharinejad S. Colon cancer cell-derived tumor necrosis factor-alpha mediates the tumor growth-promoting response in macrophages by up-regulating the colony-stimulating factor-1 pathway. Cancer Res. 2007;67:1038-1045.

41. Hagemann T, Robinson SC, Schulz M, Trümper L, Balkwill FR, Binder C. Enhanced invasiveness of breast cancer cell lines upon co-cultivation with macrophages is due to TNF-alpha dependent up-regulation of matrix metalloproteases. Carcinogenesis. 2004;25:1543-1549.

42. Egberts JH, Cloosters V, Noack A, Schniewind B, Thon L, Klose S, et al. Anti-tumor necrosis factor therapy inhibits pancreatic tumor growth and metastasis. Cancer Res. 2008;68:1443-1450.

43. Ferrajoli A, Keating MJ, Manshouri T, Giles FJ, Dey A, Estrov Z, et al. The clinical significance of tumor necrosis factor-alpha plasma level in patients having chronic lymphocytic leukemia. Blood. 2002;100:1215-1219.

44. Aroucha DC, do Carmo RF, Moura P, Silva JL, Vasconcelos LR, Cavalcanti MS, et al. High tumor necrosis factor- $\alpha$ /interleukin-10 ratio is associated with hepatocellular carcinoma in patients with chronic hepatitis C. Cy tokine. 2013;62:421-425.

45. Wang YY, Lo GH, Lai KH, Cheng JS, Lin CK, Hsu PI. Increased serum concentrations of tumor necrosis factor-alpha are associated with disease progression and malnutrition in hepatocellular carcinoma. J Chin Med Assoc. 2003;66:593-598.

46. Avrămescu CS, Comănescu V, Popescu SN, Turculeanu A, Bălăşoiu M, Popescu CF, et al. Correlations among the serum levels of some interleukins and the histopathological aspects in chronic viral hepatitis C. Rom J Morphol Embryol. 2008;49:57-62.

47. Chiu CH, Chang CC, Lin ST, Chyau CC, Peng RY. Improved Hepatoprotectivity effect of Liposome-encapsulated astaxanthin in lipopolysaccharide-induced acute hepatotoxicity. Inte J Mol sci. 2016;17:1-17.

48. Suganya V, Anuradha V, Syed Ali M, Sangeetha P, Bhuvana P. Microencapsulation and characterization of astaxanthin prepared using different agents. Res J Chem Sci. 2017;7:1-10. 
49. Mross K, Frost A, Steinbild S, Hedbom S, Büchert M, Fasol U, et al. A phase I dose-escalation study of regorafenib (BAY 73-4506), an inhibitor of oncogenic, angiogenic, and stromal kinases, in patients with advanced solid tumors. Clin Cancer Res. 2012;18: 2658-2667.

50. Reitman S, Frankel S. A Colorimetric Method for the Determination of Serum Glutamic Oxalacetic and Glutamic Pyruvic Transaminases. Am J Clin Pathol. 1957;28(1):56-63.

51. Wei Z, Doria C, Liu Y. Targeted therapies in the treatment of advanced hepatocellular carcinoma. Clin Med Insights Oncol. 2013;7:87-102.

52. Llovet JM, Ricci S, Mazzaferro V, Hilgard P, Gane E, Blanc JF. SHARP Investigators Study Group: Sorafenib in advanced hepatocellular carcinoma. N Engl J Med. 2008;359:378-390.

53. Sheppard K, Kinross KM, Solomon B, Pearson RB, Phillips WA. Targeting PI3 kinase/AKT/mTOR signaling in cancer. Crit Rev Oncog. 2012;17:69-95.

54. Dahmani R, Just PA, Perret C. The Wnt/beta-catenin pathway as a therapeutic target in human hepatocellular carcinoma. Clin Res Hepatol Gastroenterol. 2011;35:709-713.

55. Göbel T, Blondin D, Kolligs F, Bölke E, Erhardt A. Current therapy of hepatocellular carcinoma with special consideration of new and multimodal treatment concepts. Dtsch Med Wochenschr. 2013;138:1425-1430.

56. Chabner BA, Roberts TG. Timeline: Chemotherapy and the war on cancer. Nat Rev Cancer. 2005;5:65-71.

57. Mousa B. Sorafenib in the treatment of advanced hepatocellular carcinoma. The Saudi J Gastroenterol. 2008;14:40-42.

58. Desar IM, Mulder SF, Stillebroer AB, van Spronsen DJ, van der Graaf WT, Mulders PF, et al. The reverse side of the victory:flare up of symptoms after discontinuation of sunitinib orsorafenib in renal cell cancer patients, A report of three cases. Acta Oncol. 2009;48:927-931.

59. Kitada N, Kanamori K, Konishi A, Tanaka S, Suginoshita Y, Inokuma $\mathrm{T}$, et al. Analysis of factors affecting the duration of treatment with sorafenib in patients with hepatocellular carcinoma. Gan To Kagaku Ryoho. 2013;40:479-482.

60. Nakayama M, Arai Y, Nishimura K. Side effects of sorafenib and countermeasures. Hinyokika Kiyo. 2012;58:635-637.

61. Li J, Wang F, Xia Y, Dai W, Chen K, Li S, et al. Astaxanthin pretreatment attenuates hepatic ischemia reperfusion-induced apoptosis and autophagy via the ROS/MAPK pathway in mice. Mar Drugs. 2015a;13:3368-3387.
62. Li J, Xia Y, Liu T, Wang J, Dai W, Wang F, et al. Protective effects of astaxanthin on ConA-induced autoimmune hepatitis by the JNK/pJNK pathway-mediated inhibition of autophagy and apoptosis. PLoS one. 2015b;10:e120440.

63. Shen M, Chen K, Lu J, Cheng P, Xu L, Dai W, et al. Protective effect of astaxanthin on liver fibrosis through modulation of TGF-beta1 expression and autophagy. Mediat Inflamm. 2014;2014:1-10.

64. Regnier P, Bastias J, Rodriguez-Ruiz V, Caballero-Casero N, Caballo C, Sicilia D, et al. Astaxanthin from Haematococcus pluvialis prevents oxidative stress on human endothelial cells without toxicity. Mar Drugs. 2015;13:2857-2874.

65. Zhang L, Wang H. Multiple mechanisms of anti-cancer effects exerted by astaxanthin. Mar Drugs. 2015;13:4310-4330.

66. Chekanov K, Lobakova E, Selyakh I, Semenova L, Sidorov $\mathrm{R}$, Solovchenko A. Accumulation of astaxanthin by a new Haematococcus pluvialis strain BM1 from the white sea coastal rocks (Russia). Mar Drugs. 2014;12:4504-4520.

67. Guo SX, Zhou HL, Huang CL, You CG, Fang Q, Wu P, et al. Astaxanthin attenuates early acute kidney injury following severe burns in rats by ameliorating oxidative stress and mitochondrial-related apoptosis. Mar Drugs. 2015;13:2105-2123.

68. Jyonouchi H, Sun S, Iijima K, Gross MD. Antitumor activity of astaxanthin and its mode of action. Nutr Cancer. 2000;36:59-65.

69. Kowshik J, Baba AB, Giri H, Deepak Reddy G, Dixit M, Nagini S. Astaxanthin inhibits JAK/STAT-3 signaling to abrogate cell proliferation, invasion and angiogenesis in a hamster model of oral cancer. PLoS ONE. 2014;9:e109114.

70. Rao AR, Sindhuja HN, Dharmesh SM, Sankar KU, Sarada R, Ravishankar GA. Effective inhibition of skin cancer, tyrosinase, and anti-oxidative properties by astaxanthin and astaxanthin esters from the green alga Haematococcus pluvialis. J Agric Food Chem. 2013;61:3842-3851.

71. Nakao R, Nelson OL, Park JS, Mathison BD, Thompson PA, Chew BP. Effect of dietary astaxanthin at different stages of mammary tumor initiation in BALB/c mice. Anticancer Res. 2010;30:2171-2175.

72. Tripathi DN, Jena GB. Astaxanthin intervention ameliorates cyclophosphamide-induced oxidative stress, DNA damage and early hepatocarcinogenesis in rat: Role of Nrf2, p53, p38 and phase-II enzymes. Mutat Res. 2010;696:69-80.

73. Andrei S, Cernea C, Taulescu M, Catoi M. Effects of astaxanthin supplementation on chemically induced tumorigenesis in Wistar rats. Acta Vet Scand. 2014;54(50):15-18. 